\title{
Expression of AMPA/kainate receptors during development of chick embryo retina cells: in vitro versus in vivo studies
}

\author{
Armando J. Cristóvão $^{\mathrm{a}}$, Catarina R. Oliveira ${ }^{\mathrm{b}}$, Caetana M. Carvalho ${ }^{\mathrm{a}, *}$ \\ a Department of Zoology, Centre for Neuroscience of Coimbra, University of Coimbra, 3004-517 Coimbra Codex, Portugal \\ ${ }^{\mathrm{b}}$ Department of Biochemistry at the Faculty of Medicine, University of Coimbra, Coimbra, Portugal
}

Received 4 September 2001; received in revised form 24 January 2002; accepted 25 January 2002

\begin{abstract}
The activity and the subunit expression of $\alpha$-amino-3-hydroxy-5-methylisoxazole-4-propionate (AMPA)/kainate ionotropic glutamate receptors were studied in retina cells developing in chick embryos and in retina cells cultured as retinospheroids, at the same stages of development. In the retinospheroids, the activity of the AMPA/kainate receptors was monitored by following the changes in the intracellular free calcium concentration $\left(\left[\mathrm{Ca}^{2+}\right]_{\mathrm{i}}\right)$, in response to AMPA, kainate or to L-glutamate, and the expression of the receptor subunits GluR1, GluR2/3, GluR4 and GluR6/7 was determined in the retinospheroids and in chick retinas by immunodetection using polyclonal antibodies. The changes in $\left[\mathrm{Ca}^{2+}\right]_{\mathrm{i}}$ in response to $400 \mu \mathrm{M}$ kainate increased from $5 \mathrm{~h}$ in vitro to 3 days, and remained constant until day 14 , whereas the $\left[\mathrm{Ca}^{2+}\right]_{\mathrm{i}}$ in response to $500 \mu \mathrm{M}$ L-glutamate or $400 \mu \mathrm{M}$ AMPA increased from $5 \mathrm{~h}$ in vitro to 3 days, and thereafter decreased slightly until day 14 . The $\left[\mathrm{Ca}^{2+}\right]_{\mathrm{i}}$ responses to kainate are mainly due to AMPA receptor stimulation, since the signals were abolished by LY303070, the AMPA receptor antagonist, and were not affected by MK-801, the NMDA receptor antagonist. In retinospheroids, the levels of expression of GluR1 subunit increased from $5 \mathrm{~h}$ in vitro until day 7, then decreased until day 14 . The levels of expression of GluR2/3 and GluR4 subunits increased from $5 \mathrm{~h}$ in vitro until day 10 , and remained constant until day 14 . The levels of kainate receptor subunits GluR6/7 increased from $5 \mathrm{~h}$ in vitro until day 3, and thereafter decreased slightly until day 14 . In the retinas, the expression of GluR 1 and GluR6/7 subunits increased from day 8 until day 15, and then decreased until day 22 (post-natal 1). The subunits GluR2/3 and GluR4 increased from day 8 until day 18, and remained constant until day 22. The results suggest that AMPA/kainate receptors are expressed at early embryonic stages, although at low levels and before synapse formation (E12). However, the AMPA receptors are not completely functional at the first stage studied since they do not respond to the agonist AMPA. Also, the patterns of AMPA/kainate receptor subunit expression in retinospheroids of chick embryo retina cells cultured in vitro and in retina cells developing in the embryo (in vivo) were similar, indicating that the AMPA/kainate receptor subunits expression in these primary cultures mimics their expression in the developing chick retina. () 2002 ISDN. Published by Elsevier Science Ltd. All rights reserved.
\end{abstract}

Keywords: Retina; Chick; Retinospheroids; AMPA; Kainate; GluR1; GluR2/3; GluR4; GluR6/7; Development

\section{Introduction}

Glutamate is the major excitatory neurotransmitter in the retina, and acts mainly by activating ionotropic glutamate receptors (Bigge, 1999). In the CNS, these receptors are known to play a role in development (Meier et al., 1991), neuronal plasticity (Matus, 1999), dendritic spines modulation (van Rossum and Hanisch, 1999), neuronal cell death (Choi, 1988) and survival of different neuronal cell types (Balazs et al., 1988). Ionotropic glutamate receptors can be divided according to their molecular structure, sensitivity to agonists, and physiological properties into: $\alpha$-amino-3-hydroxy-5-methylisoxazole-4-propionate

\footnotetext{
* Corresponding author. Tel.: +351-239-822-752; fax: +351-239-822-776.

E-mail address: cmcarv@cnc.cj.uc.pt (C.M. Carvalho).
}

(AMPA), kainate (Bettler and Mulle, 1995) or N-methyl-Daspartate (NMDA) receptors (Dingledine et al., 1999). Several structural subtypes of AMPA receptor channel subunits exist, where GluR1-4 subunits can be assembled together in different combinations (Hollmann et al., 1989; Boulter et al., 1990; Nakanishi et al., 1990), and also cloned in the chick brain (Paperna et al., 1996). Also, several subunits of the kainate receptors have been identified: the GluR5 (Bettler et al., 1990), GluR6 (Egebjerg et al., 1991), GluR7 (Bettler et al., 1992; Lomeli et al., 1992), KA1 (Werner et al., 1991) and KA2 (Herb et al., 1992; Kamboj et al., 1992; Sakimura et al., 1992), as reviewed previously (Seeburg, 1993; Hollmann and Heinemann, 1994). The AMPA/kainate receptor channel is permeable to cations, and the activity of the receptor channel is well characterised, and can be modulated by different subunits composition (Hollmann et al., 1991; Burnashev et al., 1995), by protein kinase C (Carvalho 
et al., 1998) and by desensitising due to extracellular protons (Ihle and Patneau, 2000) (for review see Zorumski and Thio, 1992; Bleakman and Lodge, 1998).

Calcium currents induced by glutamate, alter during maturation of cortical and hippocampal neurons in culture (Wahl et al., 1989; Barish and Mansdorf, 1991), due to changes in binding sites for glutamate receptors (Wahl et al., 1991). There is also evidence for changes in AMPA activated $\mathrm{Ca}^{2+}$ currents during development (Jensen et al., 1998), glutamate receptor binding (Kumar et al., 1994), and expression of AMPA/kainate receptor during development (Hack et al., 1995; Roche and Huganir, 1995; Pickard et al., 2000) and during ageing (Nicoletti et al., 1995) in several systems. In chick retina, $\gamma$-amino-butyric acid (GABA) receptors and calcium channels are active from early days of development (Yamashita and Fukuda, 1993), and muscarinic acetylcholine responses (Yamashita et al., 1994b), as well as glutamate evoked currents (Allcorn et al., 1996; Sugioka et al., 1998), were also observed. Also, in chick retina cells in culture, glutamic acid decarboxylase expression (de Mello et al., 1991) and GABA evoked currents have been studied (Yamashita et al., 1994a), as well as calcium channels (Yamashita et al., 1994a; Capela et al., 1997), and kainate toxicity (Gibson and Reif-Lehrer, 1984; Ferreira et al., 1998).

Several studies have proposed that ionotropic glutamate receptors, including AMPA/kainate receptors, are important in neuron outgrowth (Cuppini et al., 1999), in the control of protein synthesis at developing synapses (Scheetz et al., 2000), neuronal plasticity on dendritic spines (Fischer et al., 2000) and glutamate neurotoxicity (Xia et al., 1995). Also, studies from our laboratory have shown the importance of glutamate receptors in modulating $\left[\mathrm{Ca}^{2+}\right]_{\mathrm{i}}$, as well as neurotransmitter release in the chick retina cells (Duarte et al., 1996a; Duarte et al., 1996b; Duarte et al., 1998). However, the expression and activity of AMPA/kainate receptors during retina cell development was not assessed in detail.

The aim of the present study was to investigate the expression, during development, of the AMPA/kainate receptor subunits GluR1, GluR2/3, GluR4 and GluR6/7 in chick embryo retina cells cultured as retinospheroids, during a period of 14 days in vitro (DIV), and correlated these data with the intracellular calcium changes upon AMPA/kainate receptor activation. Furthermore, to determine whether the retinospheroids are a reliable model to study the structural and functional development of glutamate receptors, we have compared the expression of the AMPA/kainate receptor subunits in the retinospheroids and in retinas with comparable time of normal development in vivo.

\section{Experimental procedures}

\subsection{Materials}

Fetal Calf Serum was obtained from Biochrom, Berlin, Germany. PVDF membranes, ECF and the secondary anti- body conjugated with alkaline phosphatase were obtained from Amersham Pharmacia Biotech, Buckinghamshire UK. Antibodies against GluR1 (AB1504) and GluR2/3 (AB1506) were from Chemicon International, Temecula, CA, USA. Antibody against GluR4 $(60666 \mathrm{~N})$ was from BD Pharmingen, San Diego, CA, USA. Antibody against GluR6/7 (\#06-309) was from Upstate Biotechnology, USA. Indo-1/AM was from Molecular Probes Inc., Eugene, OR, USA. Ionomycin was Calbiochem-Novabiochem, Darmstadt, Germany. LY303070 was a gift from Eli Lilly Co. (Indianapolis, IN). MK-801 was obtained from Merck Sharp \& Dohme Research Laboratories (Rahway, NJ). Sodium dodecyl sulphate, 30\% Acrylamide/bis (37.5:1) and Biorad protein assay were from BIORAD Laboratories, CA, USA. All other reagents were from Sigma-Aldrich, St. Louis, MO, USA, or from Merck KGaA, Darmstadt, Germany. White Leghorn eggs were obtained from a local hatchery.

\subsection{Cell culture}

Retinospheroid cultures were prepared from chick retina cells isolated from 8-day-old chick embryos, as previously described (Cristóvão et al., 1997).

\subsection{Indo-1 loading and $\left[\mathrm{Ca}^{2+}\right]_{i}$ measurements}

Chick retinospheroids with different times in culture were incubated with $2 \mu \mathrm{M}$ of Indo-1/AM, as previously described (Capela et al., 1997). The intracellular free calcium concentration $\left(\left[\mathrm{Ca}^{2+}\right]_{\mathrm{i}}\right)$ was calculated using the program "Grafical" and the formula developed by Grynkiewicz and colleagues (Grynkiewicz et al., 1985): maximal fluorescence was obtained in the presence $10 \mu \mathrm{M}$ ionomycin, and $2 \mathrm{mM} \mathrm{MnCl} 2$ was used to determine the autofluorescence (Gelfand et al., 1986).

\subsection{Preparation of fractions enriched in plasma membranes from retinospheroid cultures and from retinas}

Chick retinospheroids with increasing DIV and retinas at equivalent stages of development in vivo were used to prepare fractions enriched in plasma membranes. Retinas at different stages, were isolated as previously described (Cristóvão et al., 1997), except that the retina and the epithelium were incubated in $\mathrm{Ca}^{2+}$ - and $\mathrm{Mg}^{2+}$-free Hank's balanced salt solution for 5-10 min before the removal of the retina from the epithelium. The whole retinas or retinospheroids washed in $\mathrm{Na}^{+}$-salt solution (in $\mathrm{mM}$ : $\mathrm{NaCl} 132, \mathrm{KCl} 4, \mathrm{MgCl}_{2} 1.4$, glucose $6, \mathrm{CaCl}_{2} 1$, and 10 HEPES-NaOH, $\mathrm{pH}$ 7.4), were briefly sonicated for six times of during $5 \mathrm{~s}$ each (with $5 \mathrm{~s}$ interval) in Tris- $\mathrm{HCl}$ buffer (20 mM Tris-HCl, 2 mM EDTA, 2 mM EGTA, 1 mM PMSF, $10 \mu \mathrm{M}$ E64, $13 \mu \mathrm{M}$ benzamidine, $4 \mu \mathrm{M}$ pepstatin A, $\mathrm{pH}$ 7.4). These suspensions were centrifuged for $5 \mathrm{~min}$ at $1500 \times g$ and the supernatants were centrifuged at $12,000 \times g$ 
for $20 \mathrm{~min}$. The pellets were resuspended in Tris- $\mathrm{HCl}$ buffer supplemented with $1 \%(\mathrm{w} / \mathrm{v})$ Triton X-100 and $0.1 \%(\mathrm{w} / \mathrm{v})$ SDS. These procedures were carried out at $4{ }^{\circ} \mathrm{C}$. Protein was measured with the Biorad reagent, and denatured by dilution (1:1, v:v) in $100 \mathrm{mM}$ Tris, $100 \mathrm{mM}$ bicine, $8 \mathrm{M}$ Urea, $2 \%(w / v)$ SDS and $2 \%(w / v) \beta$-mercapoethanol), followed by $5 \mathrm{~min}$ at $95^{\circ} \mathrm{C}$, prior to SDS-poliacrylamide gels (SDS-PAGE) analysis.

\subsection{SDS-PAGE and Western blot}

Samples containing $12.5 \mu \mathrm{g}$ of protein were applied in each lane of a stacking gel of 4\% SDS-PAGE, and sized in a running gel of $7.5 \%$ SDS-poliacrylamide. Proteins were transferred electrophoretically to PVDF membranes for Western blot analysis. Membranes were blocked for $2 \mathrm{~h}$ at room temperature, in Tris-buffered saline $(137 \mathrm{mM}$ $\mathrm{NaCl}, 20 \mathrm{mM}$ Tris- $\mathrm{HCl}, \mathrm{pH}$ 7.6), containing $0.1 \%$ Tween 20 (TBS-T) and 5\% low fat milk. Immunodetection of AMPA/kainate receptor subunits was carried out using rabbit polyclonal antibodies against GluR1, GluR2/3, GluR4, GluR2, GluR6/7 and KA2 (dilutions used were 1:600, except for GluR2, 1:200 and for GluR4, 1:1000) in 1\% milk-TBS-T, by incubation overnight, at $4{ }^{\circ} \mathrm{C}$. After washing the membrane five times, for $10 \mathrm{~min}$ each, with $1 \%$ milk-TBS-T, the immunolabeling was revealed using a secondary antibody coupled to alkaline phosphatase (1:20,000 dilution, Amersham), by incubation in TBS-T with $1 \%$ low fat milk, for $1 \mathrm{~h}$ at room temperature. The membranes were then washed five times, for $10 \mathrm{~min}$ each. Protein immunoreactive bands were visualised by enhanced chemifluorescence (ECF) on a Storm $860 \mathrm{Gel}$ and Blot Imaging System (Amersham Pharmacia Biotech), after incubation of the membranes with ECF reagent for $5 \mathrm{~min}$.

\subsection{Statistical analysis}

Results are presented as mean \pm S.E.M. of the indicated number of experiments. The results were analysed using one-way ANOVA, after log transformation of the original data. Differences between treatments were determined using the Tukey-Kramer multiple comparisons test.

\section{Results}

\section{1. $\left[\mathrm{Ca}^{2+}\right]_{i}$ responses to AMPA, kainate and $\mathrm{L}$-glutamate during development of retinospheroids}

The $\left[\mathrm{Ca}^{2+}\right]_{\mathrm{i}}$ responses to the stimulation of AMPA/kainate receptors were examined at five development ages of retinospheroids. The ages tested, corresponds to embryos with 8 days (day of cell isolation) plus the number of DIV.

Stimulation of chick embryo retina cells, cultured as retinospheroids, with $400 \mu \mathrm{M}$ AMPA rapidly increase the $\left[\mathrm{Ca}^{2+}\right]_{\mathrm{i}}$, and this increase was age dependent (Fig. 1A-E). Taking the difference between basal $\left[\mathrm{Ca}^{2+}\right]_{\mathrm{i}}$ and concentra-
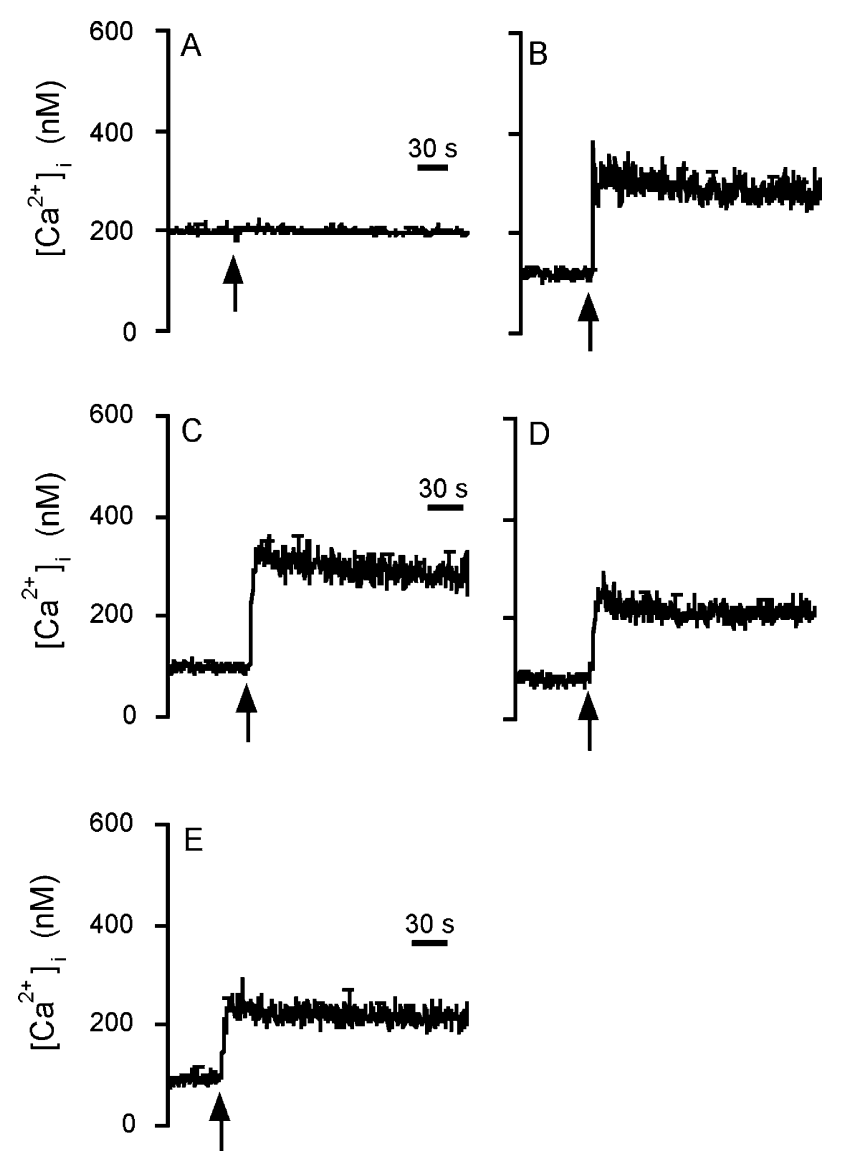

Fig. 1. $\left[\mathrm{Ca}^{2+}\right]_{\mathrm{i}}$ responses to $400 \mu \mathrm{M}$ AMPA of retinospheroids during development in vitro. Traces represent $\left[\mathrm{Ca}^{2+}\right]_{\mathrm{i}}$ responses at $5 \mathrm{~h}$ in vitro (A) and at 3, 7, 10 and 14 DIV (B-E). Indo-1 loaded retinospheroids were placed in $\mathrm{Na}^{+}$-salt solution buffer, and the $\left[\mathrm{Ca}^{2+}\right]_{\mathrm{i}}$ was measured as described in experimental procedures. Where indicated by the arrow $400 \mu \mathrm{M}$ AMPA was added to the medium. Traces represent the average of at least seven independent experiments and S.E.M. are shown every $30 \mathrm{~s}$.

tion at $20 \mathrm{~s}$ after stimulation $\left(\Delta\left[\mathrm{Ca}^{2+}\right]_{\mathrm{i}}\right)$, this difference was calculated for each developmental age (Fig. 3). We found that, in response to stimulation with $400 \mu \mathrm{M}$ AMPA, at $5 \mathrm{~h}$ in vitro, there were no changes in the $\left[\mathrm{Ca}^{2+}\right]_{\mathrm{i}}$, but at $3 \mathrm{DIV}$ the $\Delta\left[\mathrm{Ca}^{2+}\right]_{\mathrm{i}}$ increased by a value of $206.7 \pm 25.7 \mathrm{nM}$ and decreased continuously to attain a value of $139.8 \pm 10.4 \mathrm{nM}$ at 14 DIV (Fig. 3), which was significantly lower than the $\Delta\left[\mathrm{Ca}^{2+}\right]_{i}$ measured at 3 DIV (Fig. 3). It should be noted that the basal value of $\left[\mathrm{Ca}^{2+}\right]_{i}$ did not significantly change throughout development, with the exception of $5 \mathrm{~h}$ in vitro, where we observed a slightly higher value of $206.2 \pm 10.2 \mathrm{nM}$, as compared with those obtained for 3 , 7, 10, 14 DIV, $110.8 \pm 14.7,96.5 \pm 10.3,82.0 \pm 8.3$ and $93.4 \pm 13.3 \mathrm{nM}$, respectively.

Stimulation of chick embryo retina cells, cultured as retinospheroids, with $400 \mu \mathrm{M}$ kainate also rapidly increased the $\left[\mathrm{Ca}^{2+}\right]_{i}$, and this increase was age dependent (Fig. 2A-E). Taking the $\Delta\left[\mathrm{Ca}^{2+}\right]_{\mathrm{i}}$ for each developmental age (Fig. 3), in response to stimulation with $400 \mu \mathrm{M}$ kainate, the $\Delta\left[\mathrm{Ca}^{2+}\right]_{\mathrm{i}}$ increased from a value of $99.8 \pm 3.2 \mathrm{nM}$ at 

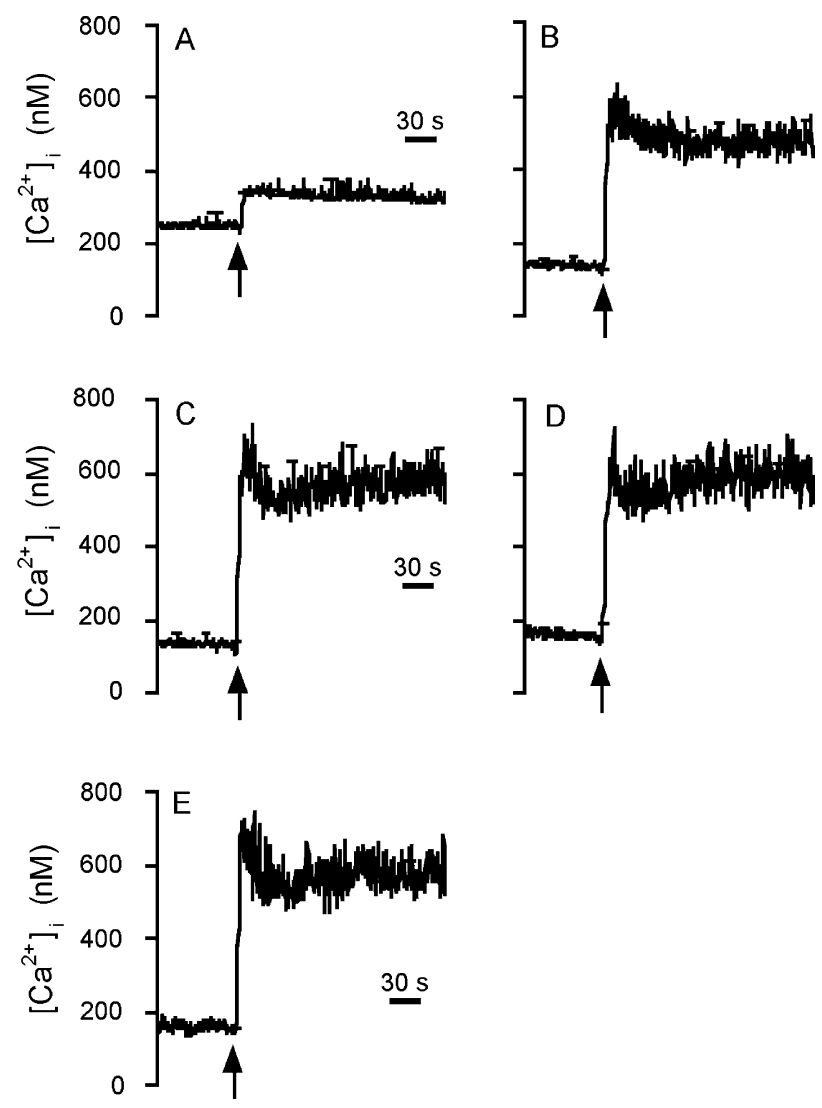

Fig. 2. $\left[\mathrm{Ca}^{2+}\right]_{\mathrm{i}}$ responses to $400 \mu \mathrm{M}$ kainate of retinospheroids during development in vitro. Traces represent $\left[\mathrm{Ca}^{2+}\right]_{\mathrm{i}}$ responses at $5 \mathrm{~h}$ in vitro (A) and at 3, 7, 10 and 14 DIV (B-E). Indo-1 loaded retinospheroids were placed in $\mathrm{Na}^{+}$-salt solution buffer, and the $\left[\mathrm{Ca}^{2+}\right]_{i}$ was measured as described in Fig. 1, except that at the arrow $400 \mu \mathrm{M}$ kainate was added to the medium. Traces represent the average of at least six independent experiments and S.E.M. are shown every $30 \mathrm{~s}$.

$5 \mathrm{~h}$ in vitro, to a value of $397.8 \pm 23.7 \mathrm{nM}$ at $3 \mathrm{DIV}$ and remained relatively constant until 14 DIV (Fig. 3). The basal values of $\left[\mathrm{Ca}^{2+}\right]_{i}$ are comparable to those reported in Fig. 1. The $\left[\mathrm{Ca}^{2+}\right]_{\mathrm{i}}$ increase due to the stimulation with kainate is mainly due to AMPA receptor activation since it was almost completely inhibited by the AMPA receptor antagonist, LY303070 $(15 \mu \mathrm{M})$, as determined for the 7 DIV cultured retinospheroids $\left(\Delta\left[\mathrm{Ca}^{2+}\right]_{\mathrm{i}}\right.$ due to kainate $423.12 \pm 32.2 \mathrm{nM}$; $\Delta\left[\mathrm{Ca}^{2+}\right]_{\mathrm{i}}$ due to kainate $\left.+\mathrm{LY} 303070,25.35 \pm 8.4 \mathrm{nM}\right)$. Also, the NMDA receptor antagonist, MK-801 $(7.5 \mu \mathrm{M})$, did not significantly affect this $\left[\mathrm{Ca}^{2+}\right]_{\mathrm{i}}$ signal, further excluding any contribution of the NMDA receptor activation $\left(\Delta\left[\mathrm{Ca}^{2+}\right]_{\mathrm{i}}\right.$ due to kainate + MK-801, $\left.411 \pm 16.5 \mathrm{nM}\right)$.

For comparison, we also followed the $\left[\mathrm{Ca}^{2+}\right]_{\mathrm{i}}$ changes in the cultured retinospheroids, when stimulated with $500 \mu \mathrm{M}$ L-glutamate. Taking the $\Delta\left[\mathrm{Ca}^{2+}\right]_{i}$ for each developmental age (Fig. 3), in response to stimulation with $500 \mu \mathrm{M}$ L-glutamate, the $\Delta\left[\mathrm{Ca}^{2+}\right]_{\mathrm{i}}$ increased from a value of $34.1 \pm$ $0.97 \mathrm{nM}$, at $5 \mathrm{~h}$ in vitro, to a value of $255.4 \pm 18.0 \mathrm{nM}$ at 3 DIV (Fig. 3), and decreased continuously to a value of $180.2 \pm 8.4 \mathrm{nM}$ at 14 DIV (Fig. 3), which was significantly

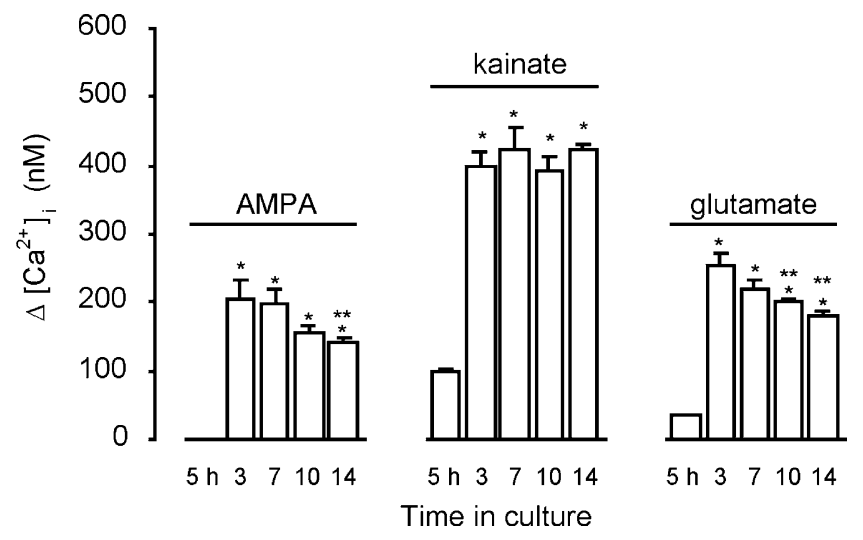

Fig. 3. Changes in intracellular free calcium $\left(\Delta\left[\mathrm{Ca}^{2+}\right]_{\mathrm{i}}\right)$ in response to $400 \mu \mathrm{M}$ AMPA, $400 \mu \mathrm{M}$ kainate or $500 \mu \mathrm{M}$ L-glutamate of retinospheroids during development in vitro $(5 \mathrm{~h}$ or $3,7,10$ and 14 days). $\Delta\left[\mathrm{Ca}^{2+}\right]_{\mathrm{i}}$ was obtained as the difference between basal $\left[\mathrm{Ca}^{2+}\right]_{\mathrm{i}}$ and $\left[\mathrm{Ca}^{2+}\right]_{i}$ at $20 \mathrm{~s}$ after stimulation, obtained from individual experiments as presented in Figs. 1 and 2. Bars represent the average of at least five independent experiments in different cultures \pm S.E.M. Significantly different from $5 \mathrm{~h}$ in vitro cells: ${ }^{*} P<0.001$. Significantly different from 3 DIV cells: ${ }^{* *} P<0.05$.

lower than the $\Delta\left[\mathrm{Ca}^{2+}\right]_{i}$ measured at 3 DIV (Fig. 3). The basal values of $\left[\mathrm{Ca}^{2+}\right]_{i}$ did not differ significantly from those reported in Fig. 2.

\subsection{Expression of AMPA/kainate receptor subunits in retinospheroids in culture}

We also examined the presence of AMPA/kainate receptor subunits at different stages of development in retina cells cultured as retinospheroids, using commercial antibodies against the subunits GluR1, GluR2/3, GluR4 and GluR6/7 (Fig. 4). It is observed that the GluR1 immunoreactivity increased in cultures from a value of $2.7 \%$ at $5 \mathrm{~h}$ in vitro (\% of relative expression of total of 5 ages studied, for each PVDF membrane analysed) to a value of $47.4 \%$ at 7 DIV (Fig. 4B), and then decreased to a value of $15.6 \%$ at 14 DIV (Fig. 4B). The GluR2/3 immunoreactivity increased from a value of $0.13 \%$ at $5 \mathrm{~h}$ in vitro to $35.6 \%$ at $10 \mathrm{DIV}$ and decreased to a value of $31 \%$ at 14 DIV (Fig. 4B). The GluR4 immunoreactivity increased from a value of $0.8 \%$ at $5 \mathrm{~h}$ in vitro to a value of $31.8 \%$ at 10 DIV and remain constant until day 14 (Fig. 4B). The GluR6/7 immunoreactivity increased from a value of $4 \%$ at $5 \mathrm{~h}$ in vitro to a value of $27.1 \%$ at $3 \mathrm{DIV}$, and decreased slightly to a value of $20.1 \%$ at 14 DIV (Fig. 4B). We could not detect any reaction with the antibody against KA2 or against two different antibodies against GluR2 (data not shown). We have determined whether the changes in the expression of AMPA/kainate receptors subunits in the cultured retina cells (Fig. 4) were due to protein concentration changes in each line load, using the cytoskeleton protein actin. The amount of this protein remained relatively constant for all samples, with the exception of $5 \mathrm{~h}$ in vitro, where it was 


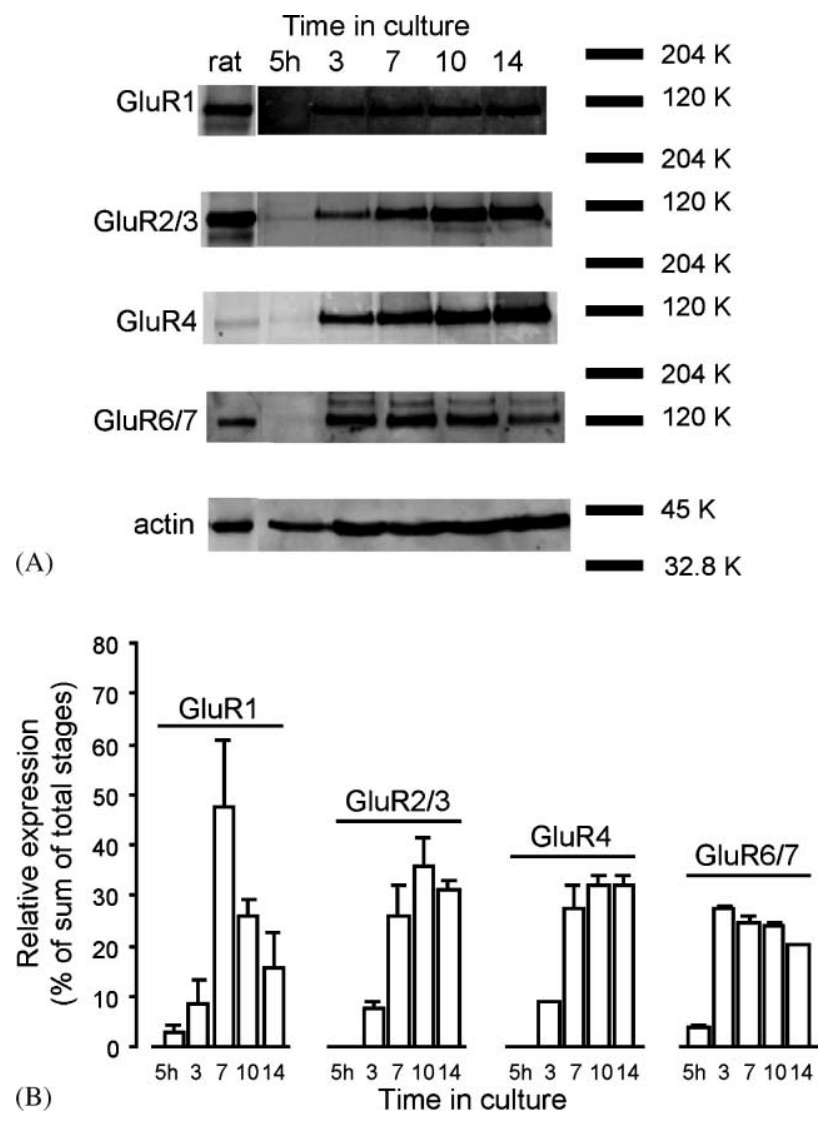

Fig. 4. Temporal expression of different AMPA/kainate receptor subunits of enriched plasmatic membranes isolated from retinospheroids, as compared to rat brain (first lane). (A) AMPA/kainate receptor subunits were sized by SDS-PAGE, and visualised by ECF, as described in experimental procedures. To test for the presence of the same amount of protein per lane, immunoreactivity of actin was followed in all samples analysed. Each lane was loaded with $12.5 \mu \mathrm{g}$ of protein (representative of three experiments). (B) Quantification of the expression profile of AMPA/kainate receptor subunits during five stages of development in vitro $(5 \mathrm{~h}$ or 3 , 7, 10 and 14 DIV) plotted as percentage of the total expression of each subunit for all the five stages studied $(n=3)$.

only $37.5 \%$ as compared to the actin present in the other stages.

\subsection{Expression of AMPA/kainate receptor subunits in the chick retina developed in the embryo}

We have further examined the presence of AMPA/kainate receptor subunits in chick retinas developed in the embryo, using the same antibodies used for AMPA/kainate receptor subunits in the retinospheroids cultures (Fig. 5). The GluR1 immunoreactivity increased in the retinas from a value of $0.27 \%$ at day 8 to a value of $39.4 \%$ at day 15 decreasing to a value of $22.0 \%$ at day 22 of development (post-natal 1) (Fig. 5B). The GluR2/3 increased from a value of $4.5 \%$ at day 8 to a value of $28.9 \%$ at day 18 , and decreased to a value of $25 \%$ at day 22 of development (Fig. 5B). The GluR4 increased continuously from a value of $2.9 \%$ at day
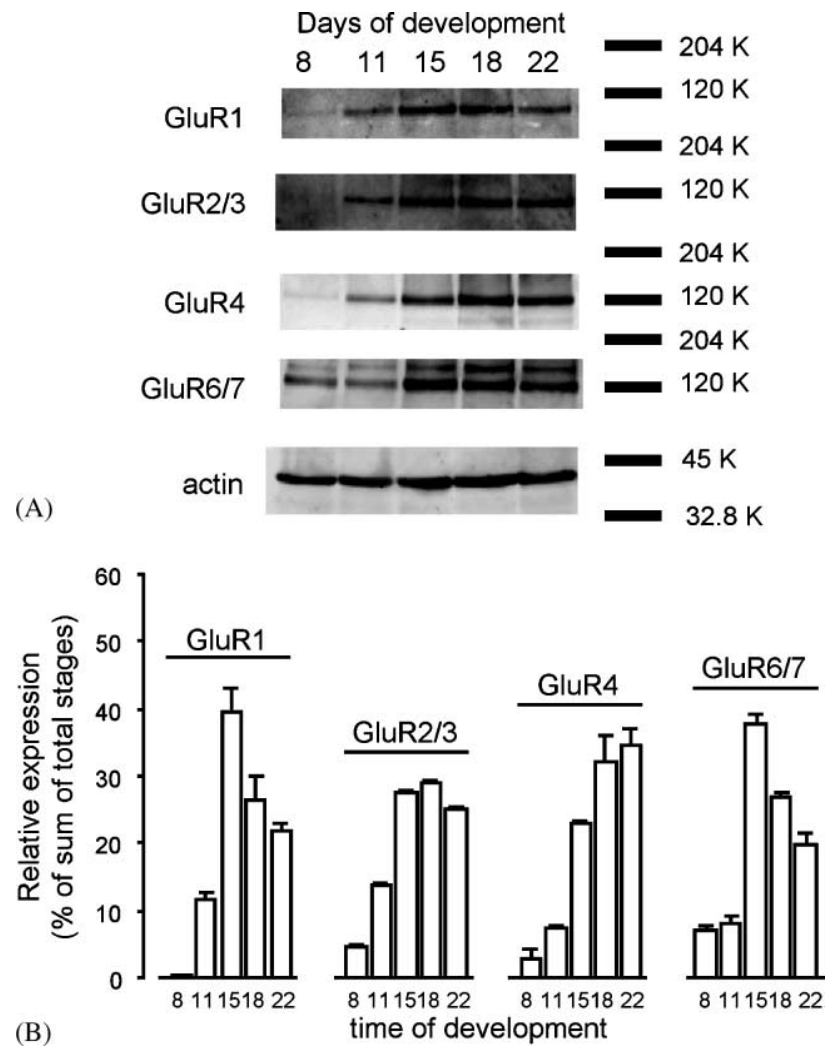

Fig. 5. (A) Temporal expression of different AMPA/kainate receptor subunits of enriched plasmatic membranes isolated from chick retinas, at the same stage of development of retinospheroids used in Fig. 4. AMPA/kainate receptor subunits were sized by SDS-PAGE, and visualised by ECF, as described in experimental procedures. To test for same amount of protein per lane, immunoreactivity of actin was followed in all samples analysed. Each lane was loaded with $12.5 \mu \mathrm{g}$ of protein (representative of three experiments). (B) Expression profile of AMPA/kainate subunits during five stages of development in vitro plotted as percentage of the total expression of each subunit for all the five stages studied $(n=3)$.

8 to a value of $34.7 \%$ at day 22 of development (Fig. 5B). The GluR6/7 immunoreactivity increased from a value of $6.9 \%$ at day 8 to a value of $37.9 \%$ at day 15 , decreasing to a value of $19.9 \%$ at day 22 of development (Fig. 5B). We could not detect any reaction with the antibody against KA2 or against two different antibodies against GluR2 (data not shown). We have also determined whether the changes observed were due to protein concentration changes in each line load, using the cytoskeleton protein actin. The amount of this protein remained relatively constant for all the samples, with the exception of $5 \mathrm{~h}$ in vitro, where it was only $58.5 \%$ as compared to the actin present in the other stages.

\section{Discussion}

\section{1. $\left[\mathrm{Ca}^{2+}\right]_{i}$ responses to AMPA, kainate and $\mathrm{L}-$ glutamate during development of retinospheroids}

In the present work we determined that the AMPA receptors were not functionally active in retinospheroids cultured 
for $5 \mathrm{~h}$ in vitro (8 days of development), but they were active at 3 DIV, and these response decreased until 14 DIV. Part of these results are not in accordance with the activity obtained in intact retinas from chick embryo (Sugioka et al., 1998), since the responses to AMPA were observed already from day 7 of development. However, these authors also observed response until day 9 , which then decreased until day 13 of development in the embryo, in accordance to our results. Also, our results are in accordance with the fact that at $5 \mathrm{~h}$ in vitro is before synapse formation in the embryo (E12) (Hering and Kroger, 1996) or synapse formation in stratospheroids of chick retina (E6 plus 8 DIV) (Hering and Kroger, 1999). The absence of response to AMPA at early stages of development in cultured retinospheroids $(5 \mathrm{~h}$ in culture) occurs in parallel to the appearance of functionally active NMDA receptors (not shown), which is in agreement to the reported sequential participation of glutamate receptors during development: first NMDA receptors followed by AMPA receptors (Ben-Ari et al., 1997). It should be noted that, the increase observed in the $\left[\mathrm{Ca}^{2+}\right]_{\mathrm{i}}$ signals from $5 \mathrm{~h}$ in vitro to 3 DIV (Fig. 3) cannot be attributed entirely to a trypsin effect in the receptors, as we previously showed for the same preparation (Capela et al., 1997).

We also observed that kainate can induce $\left[\mathrm{Ca}^{2+}\right]_{\mathrm{i}}$ responses in retinospheroids cultured for $5 \mathrm{~h}$ in vitro ( 8 days of development), and these responses increased until 3 DIV, and remained relatively constant until 14 DIV. These results are in accordance with those obtained in intact retinas from chick embryo (Allcorn et al., 1996; Sugioka et al., 1998), in which responses to kainate were observed at day 7 of development, and this response increased until day 9 and remained relatively constant until day 13 , during development in the embryo. One interesting aspect is that kainate can activate the AMPA receptors, without desensitising the AMPA receptor (Bleakman and Lodge, 1998), and in the cultured retina cells, kainate-induced calcium increase is mainly due to the activation of AMPA receptors, since LY303070, the selective AMPA receptor antagonist, almost completely abolished the response to kainate, as we have determined in 7 DIV cultured retinospheroids, and as previously reported in chick retina cells cultured as monolayers (Carvalho et al., 1998). Thus, in the present study, kainate will mainly activate AMPA receptors, and the difference between the AMPA and the kainate responses, could be explained by the desensitisation of the AMPA receptor, which may be intensively active at early embryonic stages, so that the agonist AMPA could not induce a response at $5 \mathrm{~h}$ in vitro, but kainate response is already clearly seen at this developmental stage. It should be mentioned that we have tested the possibility that the activation of AMPA/kainate receptors may cause depolarisation of the retinospheroids and lead to the release of glutamate which could activate the NMDA receptor. In fact, when we stimulated the 7 DIV cultured retinospheroids with AMPA or kainate in the presence and in the absence of MK-801, the NMDA receptor antagonist, we could not observe any differences in the $\left[\mathrm{Ca}^{2+}\right]_{\mathrm{i}}$ responses to kainate or
AMPA, indicating that NMDA receptor does not contribute significantly to these signals, at least for the time courses of the present $\left[\mathrm{Ca}^{2+}\right]_{\mathrm{i}}$ measurements.

It was also found that stimulation of cultured retinospheroids with L-glutamate lead to an increase in the $\Delta\left[\mathrm{Ca}^{2+}\right]_{i}$ that is maximum at 3 DIV and then decreased (Fig. 3). A parallel result was found in the retina of chick developed in the embryo (Sugioka et al., 1998). The development of the $\left[\mathrm{Ca}^{2+}\right]_{\mathrm{i}}$ response to $\mathrm{L}$-glutamate was similar from that obtained with AMPA, where the $\Delta\left[\mathrm{Ca}^{2+}\right]_{\mathrm{i}}$ response decreases from 3 DIV until 14 DIV. These data suggests that AMPA receptors are good candidates to be the major receptors responsible for glutamate transmission in the retinospheroids. The presence of these functionally active AMPA receptors could be important for the establishment and orientation of synapses during retinogenesis (Cuppini et al., 1999; Fischer et al., 2000; Scheetz et al., 2000), and are important for the spontaneous activity in the chick retina (Wong et al., 1998).

\subsection{Expression of AMPA/kainate receptor subunits in the chick retina: retinospheroids versus embryo}

In the chick retina, we could observe the expression of GluR1, GluR2/3 and GluR4 AMPA receptor subunits and of the kainate receptor subunits GluR6/7, both in the cultured retinospheroids and in the retina of chick embryos. The AMPA/kainate receptor subunits present in the chick retina have been previously reported in mature cat, rat and rabbit retinas (Muller et al., 1992; Hamassaki-Britto et al., 1993; Peng et al., 1995; Qin and Pourcho, 1996; Qin and Pourcho, 1999), during development (Zhang et al., 1996; Grunder et al., 2000), and more recently in rat brain (Janssens and Lesage, 2001) and hippocampal cultures (Tsuzuki et al., 2001). However, we could not detect the presence of the kainate subunit KA2, suggesting that the antibody used does not recognise this subunit in the chick (we have also tried in chick cortex and cerebellum, with no response). Thus, since there is no information available on protein data bases, we cannot exclude the possibility of the existence of KA2 in the chick retina. Also, in the present study, we could not detect any reaction with commercial antibodies against GluR2, suggesting that the GluR3 subunit is mainly contributing to the expression detected with the antibody utilised (antibody GluR2/3), which is in agreement with observations in cat retina in which the GluR2 subunit is confined to a small population of amacrine cells (Qin and Pourcho, 1999).

It is important to note that the low expression of the AMPA/kainate subunits at $5 \mathrm{~h}$ in cultured retinospheroids is not due to degradation of the receptor, because the antibodies recognise the $\mathrm{C}$-terminal of the subunits, which are inside the cell and, therefore, could not be affected by trypsin, and there are no bands different from those that appear in the blots of other stages and in the rat (not subjected to trypsin).

The most interesting result, however, is the pattern of expression of AMPA/kainate subunits, which is very similar 
in the retinospheroids and in the embryonic retina. Also, there is a similarity of the pattern of $\left[\mathrm{Ca}^{2+}\right]_{i}$ changes in response to AMPA/kainate during development of chick retinal cells cultured as retinospheroids, obtained in the present work, and the pattern obtained for the cobalt entry via AMPA/kainate receptors in embryonic chick retina during development (Allcorn et al., 1996). These results indicate that retinospheroids are a good model for studies of development, which is in agreement with our data showing that the expression of AMPA/kainate receptor subunits in these primary cultures mimic their expression in the developing chick retina. This is supported by the previous work which characterised these cultures and showed that they mimic retina stratification (Vollmer and Layer, 1986; Layer and Willbold, 1993; Rothermel et al., 1997; Hering and Kroger, 1999).

\subsection{Correlation between $\left[\mathrm{Ca}^{2+}\right]_{i}$ changes and AMPA/kainate receptors expression in retinospheroids}

As we referred to before, we could not detect functional AMPA receptors, at early embryonic days of development of the embryo chick retina, before synapse formation (Hering and Kroger, 1999), since we could not obtain a response to AMPA for $5 \mathrm{~h}$ in vitro. These results are different from what we found for the NMDA receptor in the same developmental conditions (not shown), and supports the proposed theory of sequential appearance of the NMDA and AMPA receptors (Ben-Ari et al., 1997). However, the AMPA receptor subunits are detected at these early stages, and should be expressed on the plasmatic membrane, since we can detect $\left[\mathrm{Ca}^{2+}\right]_{\mathrm{i}}$ responses when we activate the AMPA/kainate receptors with kainate, which is mainly activating AMPA receptors in these cells (Carvalho et al., 1998). These observations could be explained by the subunit composition of the AMPA receptor, and the low expression of the GluR1 at $5 \mathrm{~h}$ in vitro could explain the absence of response at this stage.

Another difference between the $\left[\mathrm{Ca}^{2+}\right]_{i}$ changes and the expression of AMPA/kainate subunits is that the $\left[\mathrm{Ca}^{2+}\right]_{\mathrm{i}}$ changes decrease from 3 DIV until 14 DIV, whereas the expression of all subunits increases at least until 7 DIV, before starting to decrease (GluR4 increases until 10 DIV, and remains constant during the studied period). This discrepancy could be explained if we assume that we are quantifying all AMPA/kainate subunits in the preparation, and not only those present in the plasma membrane which contribute to the $\left[\mathrm{Ca}^{2+}\right]_{i}$ changes. Thus, our measurement of the subunits also includes subunits that are inside the cytoplasm, due to receptor recycling mechanisms, or newly synthesised subunits which would not contribute to the $\left[\mathrm{Ca}^{2+}\right]_{i}$ changes. It is also possible that the receptor activity is being modulated by the subunits, by differences in the subunit editing, as previous reports in developing rat spinal cord (Jakowec et al., 1995).

In conclusion, the present study demonstrates that AMPA/kainate receptors are expressed at early embryonic stages in either developing retinas or in retina cells cultured as retinospheroids, but these receptors are not functionally active, since they do not respond to AMPA stimulation with an elevation in $\left[\mathrm{Ca}^{2+}\right]_{i}$ at the first stage studied. However, the receptor must be present at the plasmatic membrane since they do respond to kainate, which activates AMPA receptors. Furthermore, the expression of AMPA/kainate receptor subunits in these primary cultures mimics their expression in the developing chick retina.

\section{Acknowledgements}

We thank Professor Enrique Castro for his kind gift of the software "Grafical", utilised to analyse all the fluorimetric data. We also thank Professor A.P. Carvalho and Professor C.B. Duarte for helpful discussions during this work. This work was supported by Fundação para a Ciência e Tecnologia through Program PRAXIS XXI (2/2.1/BIA/126/94) Portugal.

\section{References}

Allcorn, S., Catsicas, M., Mobbs, P., 1996. Developmental expression and self-regulation of $\mathrm{Ca}^{2+}$ entry via AMPA/KA receptors in the embryonic chick retina. Eur. J. Neurosci. 8, 2499-2510.

Balazs, R., Hack, N., Jorgensen, O.S., 1988. Stimulation of the $N$-methyl-D-aspartate receptor has a trophic effect on differentiating cerebellar granule cells. Neurosci. Lett. 87, 80-86.

Barish, M.E., Mansdorf, N.B., 1991. Development of intracellular calcium responses to depolarisation and to kainate and $N$-methyl-D-aspartate in cultured mouse hippocampal neurons. Brain Res. Dev. Brain Res. 63, 53-61.

Ben-Ari, Y., Khazipov, R., Leinekugel, X., Caillard, O., Gaiarsa, J.L., 1997. GABA, NMDA and AMPA receptors: a developmentally regulated menage a trois. Trends Neurosci. 20, 523-529.

Bettler, B., Boulter, J., Hermans-Borgmeyer, I., O'Shea-Greenfield, A., Deneris, E.S., Moll, C., Borgmeyer, U., Hollmann, M., Heinemann, S., 1990. Cloning of a novel glutamate receptor subunit, GluR5: expression in the nervous system during development. Neuron 5, 583-595.

Bettler, B., Egebjerg, J., Sharma, G., Pecht, G., Hermans-Borgmeyer, I., Moll, C., Stevens, C.F., Heinemann, S., 1992. Cloning of a putative glutamate receptor: a low-affinity kainate-binding subunit. Neuron 8 , 257-265.

Bettler, B., Mulle, C., 1995. Neurotransmitter Receptors. Part 2. AMPA and kainate receptors neurotransmitter. Neuropharmacology 34, 123139.

Bigge, C.F., 1999. Ionotropic glutamate receptors. Curr. Opin. Chem. Biol. 3, 441-447.

Bleakman, D., Lodge, D., 1998. Neuropharmacology of AMPA and kainate receptors. Neuropharmacol. 37, 1187-1204.

Boulter, J., Hollmann, M., O’Shea-Greenfield, A., Hartley, M., Deneris, E., Maron, C., Heinemann, S., 1990. Molecular cloning and functional expression of glutamate receptor subunit genes. Science 249, 10331037.

Burnashev, N., Zhou, Z., Neher, E., Sakmann, B., 1995. Fractional calcium currents through recombinant GluR channels of the NMDA, AMPA and kainate receptor subtypes. J. Physiol. 485, 403-418.

Capela, A., Cristóvão, A., Carvalho, C., Carvalho, A.P., 1997. Ontogeny of the L-type voltage sensitive calcium channels in chick embryo retinospheroids. Brain Res. Dev. Brain Res. 104, 63-69.

Carvalho, A.L., Duarte, C.B., Faro, C.J., Carvalho, A.P., Pires, E.V., 1998. Calcium influx through AMPA receptors and through calcium channels 
is regulated by protein kinase $\mathrm{C}$ in cultured retina amacrine-like cells. J. Neurochem. 70, 2112-2119.

Choi, D.W., 1988. Glutamate neurotoxicity and diseases of the nervous system. Neuron 1, 623-634.

Cristóvão, A.J., Capela, A.N., Carvalho, C.M., 1997. $\mathrm{Ca}^{2+}$ stores in the chick embryo retina cells. Cell Signal. 9, 97-103.

Cuppini, R., Sartini, S., Ambrogini, P., Falcieri, E., Maltarello, M.C., Gallo, G., 1999. Control of neuron outgrowth by NMDA receptors. J. Submic. Cytol. Pathol. 31, 31-40.

de Mello, F.G., Hokoc, J.N., Ventura, A.L., Gardino, P.F., 1991. Glutamic acid decarboxylase of embryonic avian retina cells in culture: regulation by gamma-amino-butyric acid (GABA). Cell. Mol. Neurobiol. 11, 485496.

Dingledine, R., Borges, K., Bowie, D., Traynelis, S.F., 1999. The glutamate receptor ion channels. Pharmacol. Rev. 51, 7-61.

Duarte, C.B., Ferreira, I.L., Santos, P.F., Carvalho, A.L., Agostinho, P.M., Carvalho, A.P., 1998. Glutamate in life and death of retinal amacrine cells. Gen. Pharmacol. 30, 289-295.

Duarte, C.B., Santos, P.F., Carvalho, A.P., 1996a. $\left[\mathrm{Ca}^{2+}\right]_{\mathrm{i}}$ regulation by glutamate receptor agonists in cultured chick retina cells. Vis. Res. 36, $1091-1102$.

Duarte, C.B., Santos, P.F., Sanchez-Prieto, J., Carvalho, A.P., 1996b. Glutamate release evoked by glutamate receptor agonists in cultured chick retina cells-modulation by arachidonic acid. J. Neurosci. Res. 44, 363-373.

Egebjerg, J., Bettler, B., Hermans-Borgmeyer, I., Heinemann, S., 1991. Cloning of a cDNA for a glutamate receptor subunit activated by kainate but not AMPA. Nature 351, 745-748.

Ferreira, I.L., Duarte, C.B., Carvalho, A.P., 1998. Kainate-induced retina amacrine-like cell damage is mediated by AMPA receptors. Neuroreport 9, 3471-3475.

Fischer, M., Kaech, S., Wagner, U., Brinkhaus, H., Matus, A., 2000. Glutamate receptors regulate actin-based plasticity in dendritic spines. Nat. Neurosci. 3, 887-894.

Gelfand, E.W., Cheung, R.K., Grinstein, S., 1986. Mitogen-induced changes in $\mathrm{Ca}^{2+}$ permeability are not mediated by voltage-gated $\mathrm{K}^{+}$ channels. J. Biol. Chem. 261, 11520-11523.

Gibson, B.L., Reif-Lehrer, L., 1984. In vitro effects of kainate on embryonic and post-hatching chick retina. Brain Res. 317, 97-103.

Grunder, T., Kohler, K., Guenther, E., 2000. Distribution and developmental regulation of AMPA receptor subunit proteins in rat retina. Invest. Ophthalmol. Vis. Sci. 41, 3600-3606.

Grynkiewicz, G., Poenie, M., Tsien, R.Y., 1985. A new generation of $\mathrm{Ca}^{2+}$ indicators with greatly improved fluorescence properties. J. Biol. Chem. 260, 3440-3450.

Hack, N.J., Sluiter, A.A., Balazs, R., 1995. AMPA receptors in cerebellar granule cells during development in culture. Brain Res. Dev. Brain Res. 87, 55-61.

Hamassaki-Britto, D.E., Hermans-Borgmeyer, I., Heinemann, S., Hughes, T.E., 1993. Expression of glutamate receptor genes in the mammalian retina: the localisation of GluR1 through GluR7 mRNAs. J. Neurosci. 13, 1888-1898.

Herb, A., Burnashev, N., Werner, P., Sakmann, B., Wisden, W., Seeburg, P.H., 1992. The KA2 subunit of excitatory amino acid receptors shows widespread expression in brain and forms ion channels with distantly related subunits. Neuron 8, 775-785.

Hering, H., Kroger, S., 1996. Formation of synaptic specialisation's in the inner plexiform layer of the developing chick retinam. J. Comp. Neurol. 375, 393-405.

Hering, H., Kroger, S., 1999. Synapse formation and agrin expression in stratospheroid cultures from embryonic chick retina. Dev. Biol. 214, 412-428.

Hollmann, M., Hartley, M., Heinemann, S., 1991. $\mathrm{Ca}^{2+}$ permeability of KAAMPA-gated glutamate receptor channels depends on subunit composition. Science 252, 851-853.

Hollmann, M., Heinemann, S., 1994. Cloned glutamate receptors. Annu. Rev. Neurosci. 17, 31-108.
Hollmann, M., O'Shea-Greenfield, A., Rogers, S.W., Heinemann, S., 1989. Cloning by functional expression of a member of the glutamate receptor family. Nature 342, 643-648.

Ihle, E.C., Patneau, D.K., 2000. Modulation of alpha-amino-3-hydroxy-5methyl-4-isoxazolepropionic acid receptor desensitisation by extracellular protons. Mol. Pharmacol. 58, 1204-1212.

Jakowec, M.W., Yen, L., Kalb, R.G., 1995. In situ hybridisation analysis of AMPA receptor subunit gene expression in the developing rat spinal cord. Neuroscience 67, 909-920.

Janssens, N., Lesage, A.S.J., 2001. Glutamate receptor subunit expression in primary neuronal and secondary glial cultures. J. Neurochem. 77, $1457-1474$.

Jensen, J.B., Schousboe, A., Pickering, D.S., 1998. Development of calcium-permeable alpha-amino-3-hydroxy-5-methyl-4-isoxazolepropionic acid receptors in cultured neocortical neurons visualised by cobalt staining. J. Neurosci. Res. 54, 273-281.

Kamboj, R.K., Schoepp, D.D., Nutt, S., Shekter, L., Korczak, B., True, R.A., Zimmerman, D.M., Wosnick, M.A., 1992. Molecular structure and pharmacological characterisation of humEAA2, a novel human kainate receptor subunit. Mol. Pharmacol. 42, 10-15.

Kumar, A., Schliebs, R., Bigl, V., 1994. Post-natal development of NMDA, AMPA, and kainate receptors in individual layers of rat visual cortex and the effect of monocular deprivation. Int. J. Dev. Neurosci. 12, $31-41$.

Layer, P.G., Willbold, E., 1993. Histogenesis of the avian retina in reaggregation culture: from dissociated cells to laminar neuronal networks. Int. Rev. Cytol. 146, 1-47.

Lomeli, H., Wisden, W., Kohler, M., Keinanen, K., Sommer, B., Seeburg, P.H., 1992. High-affinity kainate and domoate receptors in rat brain. FEBS Lett. 307, 139-143.

Matus, A., 1999. Postsynaptic actin and neuronal plasticity. Curr. Opin. Neurobiol. 9, 561-565.

Meier, E., Hertz, L., Schousboe, A., 1991. Neurotransmitters as developmental signals. Neurochem. Int. 19, 1-15.

Muller, F., Greferath, U., Wassle, H., Wisden, W., Seeburg, P., 1992 Glutamate receptor expression in the rat retina. Neurosci. Lett. 138, 179-182.

Nakanishi, N., Shneider, N.A., Axel, R., 1990. A family of glutamate receptor genes: evidence for the formation of heteromultimeric receptors with distinct channel properties. Neuron 5, 569-581.

Nicoletti, V.G., Condorelli, D.F., Dell'Albani, P., Ragusa, N., Giuffrida Stella, A.M., 1995. AMPA-selective glutamate receptor subunits in the rat hippocampus during ageing. J. Neurosci. Res. 40, 220-224.

Paperna, T., Lamed, Y., Teichberg, V.I., 1996. cDNA cloning of chick brain alpha-amino-3-hydroxy-5-methyl-4-isoxazolepropionic acid receptors reveals conservation of structure, function and post-transcriptional processes with mammalian receptors. Mol. Brain Res. 36, 101-113.

Peng, Y.W., Blackstone, C.D., Huganir, R.L., Yau, K.W., 1995. Distribution of glutamate receptor subtypes in the vertebrate retina. Neuroscience 66, 483-497.

Pickard, L., Noel, J., Henley, J.M., Collingridge, G.L., Molnar, E., 2000. Developmental changes in synaptic AMPA and NMDA receptor distribution and AMPA receptor subunit composition in living hippocampal neurons. J. Neurosci. 20, 7922-7931.

Qin, P., Pourcho, R.G., 1996. Distribution of AMPA-selective glutamate receptor subunits in the cat retina. Brain Res. 710, 303-307.

Qin, P., Pourcho, R.G., 1999. Localisation of AMPA-selective glutamate receptor subunits in the cat retina: a light- and electron-microscopic study. Vis. Neurosci. 16, 169-177.

Roche, K.W., Huganir, R.L., 1995. Synaptic expression of the high-affinity kainate receptor subunit KA2 in hippocampal cultures. Neuroscience 69, 383-393.

Rothermel, A., Willbold, E., Degrip, W.J., Layer, P.G., 1997. Pigmented epithelium induces complete retinal reconstitution from dispersed embryonic chick retinae in reaggregation culture. Proc. R. Soc. London B Biol. Sci. 264, 1293-1302. 
Sakimura, K., Morita, T., Kushiya, E., Mishina, M., 1992. Primary structure and expression of the gamma 2 subunit of the glutamate receptor channel selective for kainate. Neuron 8, 267-274.

Scheetz, A.J., Nairn, A.C., Constantine-Paton, M., 2000. NMDA receptor-mediated control of protein synthesis at developing synapses. Nature Neurosci. 3, 211-216.

Seeburg, P.H., 1993. The TiPS/TINS lecture: the molecular biology of mammalian glutamate receptor channels. Trends Pharmacol. Sci. 14, 297-303.

Sugioka, M., Fukuda, Y., Yamashita, M., 1998. Development of glutamate-induced intracellular $\mathrm{Ca}^{2+}$ rise in the embryonic chick retina. J. Neurobiol. 34, 113-125.

Tsuzuki, K., Lambolez, B., Rossier, J., Ozawa, S., 2001. Absolute quantification of AMPA receptor subunit mRNAs in single hippocampal neurons. J. Neurochem. 77, 1650-1659.

van Rossum, D., Hanisch, U.K., 1999. Cytoskeletal dynamics in dendritic spines: direct modulation by glutamate receptors? Trends Neurosci. 22, 290-295.

Vollmer, G., Layer, P.G., 1986. An in vitro model of proliferation and differentiation of the chick retina: coaggregates of retinal and pigment epithelial cells. J. Neurosci. 6, 1885-1896.

Wahl, P., Honore, T., Drejer, J., Schousboe, A., 1991. Development of binding sites for excitatory amino acids in cultured cerebral cortex neurons. Int. J. Dev. Neurosci. 9, 287-296.

Wahl, P., Schousboe, A., Honore, T., Drejer, J., 1989. Glutamate-induced increase in intracellular $\mathrm{Ca}^{2+}$ in cerebral cortex neurons is transient in immature cells but permanent in mature cells. J. Neurochem. 53, 1316-1319.
Werner, P., Voigt, M., Keinanen, K., Wisden, W., Seeburg, P.H., 1991. Cloning of a putative high-affinity kainate receptor expressed predominantly in hippocampal CA3 cells. Nature 351, 742744.

Wong, W.T., Sanes, J.R., Wong, R.O., 1998. Developmentally regulated spontaneous activity in the embryonic chick retina. J. Neurosci. 18, 8839-8852.

Xia, Y., Ragan, R.E., Seah, E.E.C., Michaelis, M.L., Michaelis, E.K., 1995. Developmental expression of $N$-methyl-D-aspartate (NMDA)-induced neurotoxicity, NMDA receptor function, and the NMDAr1 and glutamate-binding protein subunits in cerebellar granule cells in primary cultures. Neurochem. Res. 20, 617-629.

Yamashita, M., Fukuda, Y., 1993. Calcium channels and GABA receptors in the early embryonic chick retina. J. Neurobiol. 24, 16001614.

Yamashita, M., Huba, R., Hofmann, H.D., 1994a. Early in vitro development of voltage- and transmitter-gated currents in GABAergic amacrine cells. Brain Res. Dev. Brain Res. 82, 95-102.

Yamashita, M., Yoshimoto, Y., Fukuda, Y., 1994b. Muscarinic acetylcholine responses in the early embryonic chick retina. J. Neurobiol. 25, 1144-1153.

Zhang, C.X., Hammassakibritto, D.E., Britto, L.R.G., Duvoisin, R.M., 1996. Expression of glutamate receptor subunit genes during development of the mouse retina. Neuroreport 8, 335340 .

Zorumski, C.F., Thio, L.L., 1992. Properties of vertebrate glutamate receptors: calcium mobilisation and desensitisation. Prog. Neurobiol. 39, 295-336. 